\title{
KESAN PENGANTARAAN PENGALAMAN PSIKOLOGI BAGI HUBUNGAN PELBAGAI KEMAHIRAN DALAM TUGAS PENGAJARAN DENGAN MOTIVASI KERJA GURU
}

\section{(THE MEDIATION EFFECT OF PSYCHOLOGICAL EXPERIENCES IN RELATION TO MULTI- SKILLS IN TEACHING DUTIES AND TEACHER WORK MOTIVATION)}

\author{
${ }^{1}$ Mat Zaini Abdullah \& ${ }^{2}$ Rafisah Osman \\ ${ }^{1 \& 2}$ Pusat Pengajian Pendidikan dan Bahasa Moden \\ Universiti Utara Malaysia \\ ${ }^{2}$ Corresponding author: rafisah@uum.edu.my
}

\begin{abstract}
ABSTRAK
Tujuan - Kajian ini bertujuan meneliti hubungan langsung faktor pelbagai kemahiran dengan motivasi kerja guru. Selain itu, kajian ini juga meneliti kesan pengantaraan pengalaman-pengalaman psikologi sebagai pemboleh ubah pengantara.
\end{abstract}

Metodologi - Kajian ini menggunakan reka bentuk korelasi yang melibatkan pengujian permodelan persamaan berstruktur dengan pendekatan kuantitatif, manakala kaedah tinjauan keratan rentas digunakan untuk pungutan data kajian. Responden kajian ini berjumlah 458 orang terdiri daripada kalangan guru sekolah menengah kebangsaan harian biasa di negeri Kedah. Teknik pensampelan rawak berkelompok telah digunakan untuk memilih responden kajian. Data kajian telah dianalisis dengan menggunakan Pemodelan Persamaan Berstruktur dan analisis lanjutan IBM SPSS melibatkan kaedah bootstrapping bagi kesan pengantaraan.

Dapatan - Hasil kajian menunjukkan pelbagai kemahiran tidak mempunyai hubungan langsung yang signifikan dengan motivasi kerja guru. Namun begitu, faktor pelbagai kemahiran didapati mempunyai hubungan langsung yang signifikan dengan pengalaman 
kerja yang bermakna, pengalaman bertanggungjawab terhadap hasil kerja dan pengetahuan sebenar hasil kerja. Analisis selang keyakinan $95 \%$ bias diperbetulkan bagi pengalaman kerja yang bermakna, pengalaman bertanggungjawab terhadap hasil kerja dan pengetahuan sebenar hasil kerja tidak mengandungi nilai sifar menunjukkan ketiga-tiga pengalaman psikologi memberi kesan pengantaraan yang signifikan.

Signifikan - Kajian ini memberi manfaat kepada penguruspengurus di sekolah dan kepimpinan pendidikan dalam merancang reka bentuk kerja guru dengan memberi tumpuan kepada pembinaan motivasi kerja melalui proses merangsang pengalaman-pengalaman psikologi guru. Dalam hal ini, pengalaman-pengalaman psikologi merupakan keberhasilan modal psikologi positif melalui penglibatan guru dalam melaksanakan tugas pengajaran. Kajian ini memberi manfaat secara langsung kepada guru dalam memahami kepentingan menggunakan pelbagai kemahiran dalam melaksanakan tugas pengajaran di sekolah.

Kata Kunci: Pelbagai kemahiran; pengalaman-pengalaman psikologi dan motivasi kerja guru.

\section{ABSTRACT}

Purpose: This study aims to seek the effect of teachers' multiskills on their motivation towards work. In addition, this study also examines the mediation effect of psychological experiences as the mediator variable.

Methodology - This study employs the correlation design which involves structured equation model assessment with a quantitative approach. Meanwhile latitudinal survey method is used for data collection. 458 secondary school teachers in the state of Kedah were selected as the respondents. Cluster random sampling was used to select the respondents. The data was analyzed using Structured Equation Modeling followed by bootstrapping for the mediation effect.

Findings - Findings showed that teachers' multi-skills do not have significant relationship with teachers' motivation towards work. However, multi-skill factors are found to have significant 
relationship with effective working experiences, responsibility experiences and real knowledge of their work output. 95\% bias in confidence interval analysis was corrected in effective working experiences, responsibility experiences and real knowledge of their work output and the absence of zero value showed that the three psychological experiences have significant mediation effect.

Significance - This study benefits school administrators and education leaders in terms of planning teachers' working design by emphasizing on the development of motivation towards work through the process of stimulating teachers' psychological experiences. Here, psychological experiences refer to positive psychological capital success through teachers' involvement in completing their teaching tasks. This study is meaningful for teachers to internalize the importance of having and using multi-skills in completing their teaching tasks in schools.

Keywords: Multi-skill, psychological experiences and teachers' motivation towards work.

\section{PENGENALAN}

Kepentingan tugas pengajaran guru di sekolah sering dikaitkan dengan keberhasilan pelajar dari aspek penguasaan pengetahuan, kemahiran dan perubahan tingkah laku serta pencapaian aspirasi dasar-dasar pendidikan negara (Kementerian Pelajaran Malaysia, 2012). Namun begitu, kepentingan tugas pengajaran kurang dikaitkan dengan keberhasilan guru dari aspek pembinaan motivasi kerja dan aspek-aspek pengalaman psikologi sedangkan teori ciriciri kerja (Job Characteristics Theory) menekankan faktor pelbagai kemahiran boleh membina motivasi kerja melalui proses mengalami pengalaman-pengalaman psikologi. Sehubungan dengan itu, kajian ini dilakukan untuk menilai sejauhmanakah faktor pelbagai kemahiran boleh mempengaruhi motivasi kerja guru melalui proses pengantaraan tiga pengalaman psikologi berasaskan teori ciri-ciri kerja.

Dalam konteks tugas pengajaran di sekolah terdapat bukti empirikal yang menunjukkan guru menggunakan kemahiran yang pelbagai untuk mencapai objektif dan meningkatkan keberkesanan pengajaran 
mereka (Misalnya kajian Shahril, 2005; Meor Ibrahim \& Nur Amira, 2013; Hairiah, 2012; Umi Nadiha, Zamri \& Jamaludin, 2011; Ab Halim \& Muhamad Khairul, 2010; Siti Fatimah \& Ab Halim, 2010; Abdul Wahab, Kamaliah \& Hasrina, 2006, Yahya, 2009). Malah Noraini (2010) dalam membincangkan isu dan cabaran dalam melaksanakan tugas pengajaran telah menggariskan lapan keperluan kemahiran untuk melaksanakan tugas pengajaran. Kemahiran tersebut terdiri dari kemahiran mengurus bilik darjah, kemahiran penilaian, kemahiran menyoal, kemahiran menggalakkan pelajar berfikir, mahir dalam menjalankan kajian tindakan untuk membaiki kualiti pengajaran dan profesional guru, mahir mengintegrasi teknologi maklumat dalam pengajaran, mahir memberi maklum balas terhadap hasil kerja pelajar dan mahir dalam membuat keputusan (Noraini, 2010). Walaupun penggunaan pelbagai kemahiran dalam tugas pengajaran berlaku, namun kurang bukti empirikal yang menunjukkan wujud hubungan antara faktor pelbagai kemahiran dengan motivasi kerja melalui kesan pengantaraan pengalamanpengalaman psikologi dalam konteks guru sebagai responden.

Dalam hal ini, teori ciri-ciri kerja menekankan faktor pelbagai kemahiran dalam reka bentuk kerja berperanan menyediakan peluang kepada pekerja untuk menggunakan kemahiran, keupayaan dan bakat yang berbeza dalam melaksanakan kerja (Hackman \& Oldham, 1980). Namun jika dilihat daripada sudut pandangan pekerja, faktor pelbagai kemahiran merupakan pengetahuan dan kemahiran-kemahiran yang diperlukan untuk melaksanakan kerja dan merupakan tuntutan kerja yang boleh melibatkan tekanan kerja, tuntutanemosi, mental danfizikal (Humphrey, Nahrgang \& Morgeson, 2007; Bakker \& Demerouti, 2007; Demerouti, Bakker, Nachreiner \& Schaufeli, 2001). Guru merupakan individu yang terlatih dan berkemahiran untuk melaksanakan tugas pengajaran di sekolah. Keseimbangan antara tuntutan tugas pengajaran dan kemahiran guru boleh membina peluang untuk guru merasai kecekapan diri dalam melaksanakan tugas pengajaran dan memudahkan proses membina motivasi kerja (Csikszentmihaly, 1990).

Secara praktis, teori ciri-ciri kerja mengandaikan faktor pelbagai kemahiran terlebih dahulu perlu mempunyai hubungan langsung dengan pengalaman kerja yang bermakna sebelum proses motivasi kerja berlaku (Hackman \& Oldham, 1980). Namun begitu, kajiankajian terkini mendapati hubungan faktor pelbagai kemahiran 
dengan motivasi kerja boleh berlaku tanpa melalui pengalaman kerja yang bermakna (Nazila \& Seyed, 2014; Isfahani, Bahrami \& Torki, 2013; Mohammad Hadi, 2013; Nadeem, Anwar \& Shaikh, 2012; Aneel, Qaisar, Ikhtiar \& Ashi, 2011; Rabia \& Adnan, 2010). Malahan kajian-kajian lebih awal mendapati hubungan secara langsung faktor pelbagai kemahiran dengan motivasi kerja tanpa melalui pengalaman kerja yang bermakna sebagai pemboleh ubah pengantara boleh meningkatkan kuasa peramal faktor pelbagai kemahiran terhadap motivasi kerja (Boonzaier, Ficker, \& Rust, 2001; Fried \& Ferris, 1987; Hogan \& Martell, 1987).

Sementara itu, analisis meta yang dilakukan oleh Humphrey et. al (2007) telah menimbulkan beberapa persoalan tentang kesan pengantaraan yang dicadangkan oleh teori ciri-ciri kerja. Analisis mendapati di samping pengalaman kerja yang bermakna, pengalaman bertanggungjawab terhadap hasil kerja dan pengetahuan sebenar hasil kerja juga memberi kesan pengantaraan yang signifikan terhadap hubungan antara faktor pelbagai kemahiran dengan motivasi kerja. Dapatan ini secara langsung bertentangan dengan andaian teori ciri-ciri kerja yang menegaskan kesan pengantaraan bagi hubungan faktor pelbagai kemahiran dengan motivasi kerja hanya berlaku melalui pengalaman kerja yang bermakna (Hackman \& Oldham, 1980). Dapatan dan gambaran yang tidak konsisten ini memerlukan kajian baru yang dilakukan secara lebih menyeluruh.

\section{SOROTAN KARYA}

Teori ciri-ciri kerja mengandaikan faktor pelbagai kemahiran hanya mempunyai hubungan dengan motivasi kerja melalui kesan pengantaraan pengalaman kerja yang bermakna (Hackman \& Oldham, 1980). Andaian ini disokong oleh beberapa kajian yang menunjukkan terdapat kesan pengantaraan yang signifikan pengalaman kerja yang bermakna terhadap hubungan antara faktor pelbagai kemahiran dengan motivasi kerja (Shani \& AnandKumar, 2011; Humphrey et. al, 2007; Behson, Eddy \& Lorenzat, 2000; Renn \& Vandenberg, 1995). Sebaliknya teori ciri-ciri kerja tidak mengandaikan pengalaman bertanggungjawab terhadap hasil kerja dan pengetahuan sebenar hasil kerja memberi kesan pengantaraan yang signifikan bagi hubungan antara faktor pelbagai kemahiran dengan motivasi kerja (Hackman \& Oldham, 1980). 
Teori ciri-ciri kerja yang menjadi kerangka teoritikal utama kajian ini merupakan teori reka bentuk kerja yang menekankan pembinaan motivasi kerja berasaskan ciri-ciri kerja yang bersifat intrinsik seperti faktor pelbagai kemahiran (Hackman \& Oldham, 1980; Champoux, 2011; Faturochman, 1997). Mengikut teori ciri-ciri kerja, motivasi kerja yang dikaji diistilahkan sebagai motivasi kerja dalaman (internal work motivation) yang merujuk kepada perasaan positif yang dialami secara dalaman apabila pekerja dapat melaksanakan kerja dengan berkesan atau baik (Hackman \& Oldham, 1980). Motivasi kerja dalaman terbentuk berasaskan anteseden yang tidak kelihatan dalam kandungan kerja melalui pembinaan pengalamanpengalaman psikologi dalam diri pekerja seterusnya merangsang perasaan positif sebagai salah satu elemen penting motivasi kerja (Hackman \& Oldham, 1980; Hackman \& Oldham, 1976). Dalam hal ini, proses merangsang dan meningkatkan motivasi kerja guru adalah penting bagi mencapai keberkesanan pengajaran pada tahap yang maksimum (Norashid \& Hamzah, 2014).

Dalam kajian ini, pengalaman kerja yang bermakna merujuk kepada pengalaman kerja yang boleh memberi makna secara peribadi dan dianggap berharga kepada guru mengikut sistem nilai yang menjadi pegangan mereka (Hackman \& Oldham, 1975, 1980). Bessette (2003) menekankan pengalaman kerja bermakna sebagai persepsi positif secara dalaman terhadap kerja yang menjadi keperluan asas untuk mencari makna dan tujuan utama dalam melakukan kerja. Pengalaman kerja juga dianggap sebagai perasaan positif yang terhasil daripada interaksi antara pekerja dengan organisasi kerja dan kandungan kerja (Kristensen, Hannerz, Hogh \& Borg, 2005), manakala Treadgold (1999) menganggapnya sebagai persepsi positif terhadap kerja yang menjadi faktor individu dimotivasikan secara intrinsik untuk melaksanakan kerja dan rasa untuk melaksanakannya dipandu oleh dorongan dalaman. Dalam hal ini, Yalom (1980) menegaskan manusia memerlukan pengalaman yang bermakna untuk memahami dan mentafsirkan pengalaman mereka dalam melaksanakan kerja serta mendefinisikan nilai-nilai yang menjadi asas tindakan mereka.

Seterusnya, pengalaman bertanggungjawab terhadap hasil kerja merupakan perasaan bertanggungjawab dan rasa akauntabiliti secara peribadi terhadap hasil kerja yang dilakukan (Hackman \& Oldham, 1980). Dalam konteks guru, pengalaman bertanggungjawab 
merupakan salah satu faktor penting yang mempengaruhi keberhasilan proses pengajaran dan pembelajaran (Dahlgren \& Hammar, 2009; Lauermann \& Karabenick, 2011, 2013). Pengalaman bertanggungjawab menjelaskan rasa dalaman dan komitmen untuk menyumbang kepada keberhasilan matlamat kerja dan mempertahankan keberhasilan matlamat tersebut (Lauermann \& Karabenick, 2011). Dalam hal ini, pengalaman bertanggungjawab boleh melibatkan perasaan guru terhadap amalan pengajaran, pembelajaran pelajar dan prestasi pelajar (Lauermann \& Karabenick, 2013), selain melibatkan rasa tanggungjawab terhadap motivasi pelajar untuk belajar, kejayaan akademik pelajar dan tanggungjawab dalam interaksi guru dengan pelajar (Lauermann \& Karabenick, 2013). Oleh itu, pengalaman bertanggungjawab memerlukan guru memahami secara mendalam tentang tanggungjawab mereka dan situasi yang memerlukan mereka bertanggungjawab secara peribadi untuk setiap hasil kerja yang dilakukan (Lauermann \& Karabenick, 2013).

Faktor terakhiryang diuji dalam kajian ini adalah pengetahuan sebenar hasil kerja yang merupakan kefahaman dan pengetahuan yang jelas serta berterusan guru terhadap keberkesanan atau kecekapan mereka dalam melaksanakan kerja (Hackman \& Oldham, 1980). Dalam soal ini, Dewey (1933) menegaskan individu yang mempunyai pengetahuan sebenar hasil kerja sentiasa aktif dalam memikirkan masalah yang dihadapi, gigih mencari jalan penyelesaian, sedia mengorbankan masa untuk memastikan masalah yang dihadapi dapat diatasi dan sentiasa menerima pandangan yang berpotensi untuk menyelesaikan masalah. Bagi Boud, Keogh dan Walker (1985) pengetahuan sebenar hasil kerja berperanan meneutralkan kembali segala perasaan negatif yang menyelubungi pengalaman yang lalu supaya satu perspektif baru dapat dihasilkan daripada pengalaman tersebut sekaligus mengubah tingkah laku dan tindakan seseorang.

Sementara itu, sorotan karya juga menunjukkan hubungan antara faktor pelbagai kemahiran dengan pengalaman-pengalaman psikologi tidak konsisten dan bercampur-campur. Di samping mempunyai hubungan dengan pengalaman kerja yang bermakna sebagaimana cadangan khusus teori ciri-ciri kerja (Hackman \& Oldham, 1980; Champoux, 2011; Bremner \& Carriere, 2011; Humphrey et. al, 2007; Lee Ross, 1996; Renn \& Vandenberg, 1995), faktor pelbagai kemahiran juga mempunyai hubungan dengan 
pengalaman bertanggungjawab terhadap hasil kerja dan pengetahuan sebenar hasil kerja (Behson, 2012; Humphrey et. al, 2007). Hal ini menyebabkan Boonzaier et. al (2001) membuat kesimpulan bahawa pengaruh atau hubungan hanya antara faktor pelbagai kemahiran dengan pengalaman kerja yang bermakna untuk membina motivasi kerja sebagaimana andaian teori ciri-ciri kerja sukar disahkan kerana dapatan kajian yang berbeza dan tidak konsisten sebagaimana andaian teori. Namun dapatan tersebut membuka ruang kepada pengujian teori yang lebih pratikal dengan laluan-laluan yang lebih terbuka untuk menjelaskan proses pembinaan motivasi kerja.

\section{OBJEKTIF KAJIAN}

Objektif utama kajian ini adalah untuk:

1. Meneliti hubungan langsung faktor pelbagai kemahiran dalam tugas pengajaran dengan motivasi kerja guru.

2. Meneliti hubungan langsung antara faktor pelbagai kemahiran dalam tugas pengajaran dengan pengalaman-pengalaman psikologi.

3. Meneliti kesan tak langsung faktor pelbagai kemahiran dalam tugas pengajaran terhadap motivasi kerja guru melalui kesan pengantaraan pengalaman-pengalaman psikologi.

\section{METODOLOGI}

Kajian ini menggunakan reka bentuk kajian korelasi yang melibatkan pengujian permodelan persamaan berstruktur dengan pendekatan kuantitatif untuk menjelaskan hubungan faktor pelbagai kemahiran dalam tugas pengajaran untuk mempengaruhi motivasi kerja guru melalui pemboleh ubah pengalaman psikologi dan fenomenanya pada masa sekarang (Gay \& Diehl, 1996). Di samping itu, kajian ini juga ingin mengenal pasti pengaruh antara pemboleh ubah untuk tujuan membuat ramalan (Gay \& Diehl, 1996).

Sementara itu, kaedah tinjauan keratan rentas (cross sectional survey) digunakan untuk tujuan pungutan data kajian. Kaedah tinjauan keratan rentas dianggap sesuai digunakan kerana sampel bertaburan dalam saiz populasi yang besar tetapi saiz sampel telah ditentukan 
oleh penyelidik dan maklumat dapat dikumpulkan pada satu titik masa tertentu (single point in time) (Noraini, 2010; Creswell, 2012; Cohen, Manion \& Morrison, 2011). Penggunaan kaedah tinjauan juga merupakan cara terbaik bagi mengukur persepsi, sikap, kepercayaan, pendapat, praktis dan orientasi untuk saiz populasi yang besar (Babbie, 2008; Creswell, 2012). Mengikut Richey dan Klein (2007) kaedah tinjauan sering digunakan bagi kajian yang berkait dengan pembangunan atau pengujian teori, sekiranya ralat dapat dikawal, dapatan kajian boleh digeneralisasikan kepada populasi (Miller, 2003).

Responden sebenar kajian adalah seramai 458 orang terdiri daripada guru-guru sekolah menengah kebangsaan harian biasa di negeri Kedah. Kaedah pemilihan responden kajian menggunakan teknik pensampelan rawak berkelompok (Chua, 2011; Noraini, 2010; Ahmad Mahdzan, 2007). Peringkat pertama individu guru sekolah menengah kebangsaan harian biasa sebagai unit analisis dikelompok berdasarkan sekolah mengikut daerah pendidikan masing-masing dan setiap sekolah dianggap sebagai satu kelompok untuk tujuan pensampelan. Peringkat kedua setiap sekolah diberi nombor siri daripada 1 hingga 113 mengikut daerah pendidikan supaya semua sekolah mempunyai peluang yang sama untuk dipilih mewakili daerah pendidikan masing-masing dan bertujuan mewujudkan keseimbangan dari segi bilangan sekolah untuk setiap daerah pendidikan. Peringkat ketiga daripada 113 kelompok sekolah sebanyak 20 buah sekolah (5 buah sekolah bagi setiap daerah pendidikan) telah dipilih dengan menggunakan teknik pensampelan rawak mudah. Setiap sekolah diwakilli oleh 30 orang guru sebagai responden yang dipilih menggunakan teknik pensampelan rawak mudah. Kajian ini telah melibatkan empat daerah pentadbiran pendidikan di negeri Kedah.

\section{INSTRUMEN KAJIAN}

Kajian ini menggunakan instrumen Work Design Questionnaire (WDQ) oleh Morgeson dan Humphrey (2006) yang diadaptasi bagi mengukur faktor pelbagai kemahiran. Seterusnya pemboleh ubah tiga faktor pengalaman psikologi dan motivasi kerja guru diukur dengan menggunakan Job Diagnostics Survey (JDS) oleh Hackman dan Oldham (1975). Faktor pelbagai kemahiran diukur dengan menggunakan 4 item, faktor pengalaman kerja yang bermakna 
(4 item), pengalaman bertanggungjawab terhadap hasil kerja (5 item), pengetahuan sebenar hasil kerja (4 item) dan motivasi kerja guru (5 item). Kesemua item berbentuk pernyataan positif kecuali 4 item, iaitu dua item (PM6 dan PM8) yang mengukur pengalaman kerja yang bermakna dan dua item (PS15 dan PS17) yang mengukur pengetahuan sebenar hasil kerja. Keempat-empat item dikod semula secara terbalik pada item yang sama untuk tujuan analisis. Instrumen kajian ini menggunakan skala jenis LIKERT lima mata dengan $1=$ sangat tidak bersetuju; $2=$ tidak bersetuju; $3=$ sederhana setuju; $4=$ bersetuju dan $5=$ sangat bersetuju.

Bagi memperoleh kesahan muka, item-item asal telah diterjemahkan oleh penyelidik dan Institut Terjemahan dan Buku Malaysia (ITBM). Kemudian disemak oleh dua orang guru bahasa Inggeris berasaskan kaedah back translation (Brislin, 1970). Bagi semakan struktur ayat bahasa Melayu, penyelidik telah menggunakan khidmat dua orang guru bahasa Melayu yang berpengalaman. Lima orang guru dipilih untuk diuji kefahaman mereka terhadap item-item melalui proses menjawab instrumen dan soal jawab lisan. Sebelum diedarkan untuk pungutan data sebenar, instrumen disemak sekali lagi oleh dua orang pensyarah di Universiti Utara Malaysia. Pungutan data dibuat dengan menggunakan kaedah serahan tangan setelah kebenaran daripada Kementerian Pendidikan Malaysia dan Jabatan Pendidikan Negeri Kedah serta pengetua sekolah berkaitan diperoleh.

\section{ANALISIS DATA}

Analisis faktor pengesahan menggunakan perisian AMOS 21 dilakukan untuk tujuan kesahan instrumen. Kesahan instrumen dinilai daripada tiga aspek, iaitu kesahan menumpu, kesahan membeza dan kesahan nomologikal (Hair, Black, Babin \& Anderson, 2010). Seterusnya, analisis pemodelan persamaan berstruktur dilaksanakan untuk meneliti kesan langsung faktor pelbagai kemahiran terhadap motivasi kerja guru dan pengalaman-pengalaman psikologi menggunakan kaedah bootstrapping dengan pensampelan semula 2000 kali melibatkan selang keyakinan $95 \%$ bias diperbetulkan (Bias Corrected 95\% Confident Interval). Analisis lanjutan IBM SPSS 22 melibatkan kaedah bootstrapping dengan pensampelan semula sebanyak 2000 kali dan 95\% selang keyakinan bias diperbetulkan (Bias corrected 95\% Confident Interval) digunakan untuk menilai kesan pengantaraan spesifik pengalaman-pengalaman psikologi bagi 
hubungan antara faktor pelbagai kemahiran dengan motivasi kerja guru. Kaedah ini melibatkan proses impute pemboleh-pemboleh ubah kajian dalam pemodelan persamaan berstruktur (Preachers \& Hayes, 2008). Nisbah kesan bagi perbandingan kesan pengantaraan yang lebih signifikan antara pemboleh ubah pengantara digunakan dalam kajian ini dan dianggap lebih baik berbanding penggunaan kaedah pengantara penuh atau separa (Shrout \& Bolger, 2002). Rumus bagi mengira nisbah kesan sebagaimana di bawah:

Nisbah $=\frac{\text { Kesan tak langsung }}{\text { Kesan keseluruhan }}$

\section{Analisis Faktor Pengesahan}

Rajah 1 menunjukkan model pengukuran akhir lima faktor kajian yang mencapai tahap kesepadanan yang baik setelah proses kovarian error term dilakukan secara berperingkat berdasarkan nilai indeks modifikasi kovarians melebihi 15 (Zainuddin, 2012). Kriteria tahap kesepadanan dinilai berasaskan cadangan Hair et.al (2010), iaitu satu petunjuk Absolute Fit Index (AFI) dan satu petunjuk Incremental Fit Index (IFI) sebagai tambahan kepada petunjuk nilai khi kuasa dua.

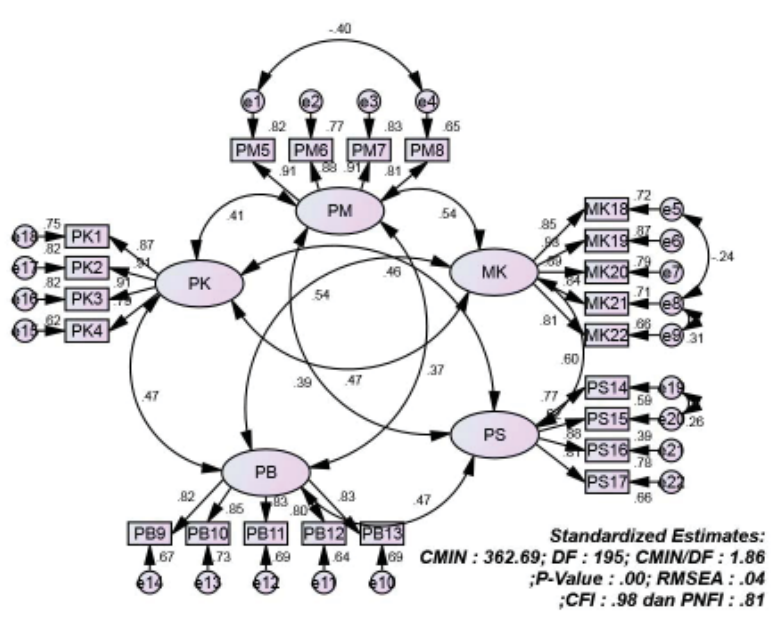

Rajah 1. Model Pengukuran Keseluruhan Akhir Lima Faktor Kajian

Nota: $\mathrm{PK}=$ pelbagai kemahiran; $\mathrm{PM}=$ pengalaman kerja yang bermakna; $\mathrm{PB}=$ pengalaman bertanggungjawab terhadap hasil kerja; $\mathrm{PS}=$ pengetahuan sebenar hasil kerja; $\mathrm{MK}=$ motivasi kerja 
Sementara itu, Jadual 1 menunjukkan dua petunjuk AFI memberi nilai ketepatan padanan yang baik, iaitu RMSEA $=.04$ dan CMIN/ $\mathrm{DF}=1.86$. Kedua-dua petunjuk memenuhi nilai yang ditetapkan (Hair et.al, 2010). Bagi petunjuk IFI, nilai CFI $=.98$ melebihi nilai .90 yang ditetapkan berdasar kerumitan model dan saiz sampel. Walaupun model ini tidak dibandingkan dengan model lain, Parsimony Fit Index (PFI) turut diambil kira. Nilai PNFI $=.81$ melebihi .60 menunjukkan model pengukuran keseluruhan akhir lima faktor kajian mencapai ketepatan padanan yang baik dan sesuai digunakan untuk analisis selanjutnya.

Jadual 1

Petunjuk Ketepatan Padanan Model Pengukuran Keseluruhan Akhir Lima Faktor Kajian

\begin{tabular}{lccc}
\hline \multicolumn{1}{c}{ Petunjuk } & $\begin{array}{c}\text { Nilai Petunjuk } \\
\text { Diterima }\end{array}$ & \multicolumn{2}{c}{ Nilai Kesepadanan } \\
\cline { 3 - 4 } & & $\begin{array}{c}\text { Analisis } \\
\text { Awal }\end{array}$ & $\begin{array}{c}\text { Analisis } \\
\text { Akhir }\end{array}$ \\
\hline Absolute Fit Indices & & & \\
CMIN $\left(\chi^{2}\right)$ & - & 476.54 & 362.69 \\
DF & - & 199 & 195 \\
CMIN/DF & $<3$ & 2.40 & 1.86 \\
PROB (P - Val) & $>.05$ & .00 & .00 \\
RMSEA & $<.08$ & .06 & .04 \\
Incremental Fit Indices & & & \\
CFI & $>.90$ & .97 & .98 \\
Parsimony Fit Indices & & & \\
PNFI & $>.60$ & .81 & .81 \\
\hline
\end{tabular}

\section{Kesahan Menumpu}

Jadual 2 menunjukkan wujud kesahan menumpu item-item untuk mengukur setiap faktornya apabila nilai kebolehpercayaan konstruk (Pc) melebihi .60 dan lebih besar berbanding purata varians teresktrak (AVE) dengan nilai AVE melebihi .50 (Hair et. al, 2010). Sementara itu, data univariat didapati bertaburan normal dengan nilai skewness dan kurtosis tidak melebihi 2 (Tabachnick \& Fidell, 2007; Kline, 2005). 
Jadual 2

Kesahan Menumpu Lima Faktor Kajian

\begin{tabular}{|c|c|c|c|c|c|c|c|c|}
\hline Bil & Faktor & Item & Skew & Kurtosis & $\lambda$ & SMC & Pc & AVE \\
\hline 1 & PK & $\begin{array}{l}\text { PK1 } \\
\text { PK2 } \\
\text { PK3 } \\
\text { PK4 }\end{array}$ & $\begin{array}{l}-.51 \\
-.43 \\
-.43 \\
-.37\end{array}$ & $\begin{array}{l}-.03 \\
-.05 \\
-.23 \\
-.14\end{array}$ & $\begin{array}{l}.87 \\
.91 \\
.91 \\
.79\end{array}$ & $\begin{array}{l}.75 \\
.82 \\
.82 \\
.62\end{array}$ & .92 & .75 \\
\hline 2 & PM & $\begin{array}{l}\text { PM5 } \\
\text { PM6 } \\
\text { PM7 } \\
\text { PM8 }\end{array}$ & $\begin{array}{c}.03 \\
-.01 \\
-.14 \\
.21\end{array}$ & $\begin{array}{l}-1.21 \\
-1.03 \\
-1.17 \\
-1.22\end{array}$ & $\begin{array}{l}.89 \\
.89 \\
.92 \\
.78\end{array}$ & $\begin{array}{l}.79 \\
.79 \\
.85 \\
.61\end{array}$ & .93 & .76 \\
\hline 3 & PB & $\begin{array}{l}\text { PB9 } \\
\text { PB10 } \\
\text { PB11 } \\
\text { PB12 } \\
\text { PB13 }\end{array}$ & $\begin{array}{l}-.46 \\
-.41 \\
-.52 \\
-.35 \\
-.68\end{array}$ & $\begin{array}{c}-.05 \\
-.15 \\
.17 \\
-.56 \\
.69\end{array}$ & $\begin{array}{l}.82 \\
.86 \\
.83 \\
.80 \\
.83\end{array}$ & $\begin{array}{l}.67 \\
.73 \\
.69 \\
.64 \\
.69\end{array}$ & .92 & .68 \\
\hline 4 & PS & $\begin{array}{l}\text { PS14 } \\
\text { PS15 } \\
\text { PS16 } \\
\text { PS17 }\end{array}$ & $\begin{array}{l}.06 \\
-.46 \\
.12 \\
.02\end{array}$ & $\begin{array}{l}-.89 \\
-.38 \\
-.80 \\
-.93\end{array}$ & $\begin{array}{l}.79 \\
.66 \\
.87 \\
.81\end{array}$ & $\begin{array}{l}.63 \\
.44 \\
.75 \\
.66\end{array}$ & .87 & .62 \\
\hline 5 & MK & $\begin{array}{l}\text { MK18 } \\
\text { MK19 } \\
\text { MK20 } \\
\text { MK21 } \\
\text { MK22 }\end{array}$ & $\begin{array}{c}.31 \\
.13 \\
.20 \\
-.04 \\
.07\end{array}$ & $\begin{array}{l}-.67 \\
-.90 \\
-.88 \\
-.87 \\
-.76\end{array}$ & $\begin{array}{l}.83 \\
.93 \\
.89 \\
.85 \\
.83\end{array}$ & $\begin{array}{l}.70 \\
.86 \\
.79 \\
.72 \\
.69\end{array}$ & .94 & .75 \\
\hline
\end{tabular}

Nota: $P K=$ pelbagai kemahiran $; P M=$ pengalaman kerja yang bermakna $P B$ = pengalaman bertanggungjawab terhadap hasil kerja; $P S=$ pengetahuan sebenar hasil kerja; $M K=$ motivasi kerja; $\lambda=$ beban faktor; $S M C=$ squared multiple correlations (korelasi kuasa dua berganda); Pc = construct reliability (kebolehpercayaan konstruk); AVE = average variance extracted (purata varians terestrak)

\section{Kesahan Membeza}

Jadual 3 menunjukkan terdapat kesahan membeza antara faktor berdasarkan nilai punca kuasa dua AVE lebih besar berbanding nilai korelasi faktor dengan faktor lain (Hair et. al, 2010; Fornell \& Lacker, 1981). Faktor motivasi kerja berbeza dengan faktorfaktor lain kerana nilai punca kuasa AVEnya pada .87 melebihi nilai korelasi faktor motivasi kerja dengan pengalaman kerja yang bermakna (.53), pelbagai kemahiran (.47), pengetahuan sebenar hasil kerja (.59) dan pengalaman bertanggungjawab terhadap hasil kerja (.54). 
Jadual 3

Kesahan Membeza Lima Faktor Kajian

\begin{tabular}{lccccc}
\hline \multicolumn{1}{c}{ Faktor } & MK & PM & PK & PS & PB \\
\hline MK & .87 & - & - & - & - \\
PM & .53 & .87 & - & - & - \\
PK & .47 & .41 & .87 & - & - \\
PS & .59 & .38 & .46 & .79 & - \\
PB & .54 & .37 & .47 & .48 & .83 \\
\hline
\end{tabular}

Nota: $P K=$ pelbagai kemahiran; $P M=$ pengalaman kerja yang bermakna; $P B=$ pengalaman bertanggungjawab terhadap hasil kerja; $P S=$ pengetahuan sebenar hasil kerja; $M K=$ motivasi kerja

\section{Kesahan Nomologikal}

Jadual 4 menunjukkan kesahan nomologikal yang dinilai berasaskan nilai korelasi antara faktor-faktor kajian. Hubungan setiap faktor kajian yang signifikan dan mengikut arah cadangan teori ciriciri kerja yang mendasari kajian ini menunjukkan wujud kesahan nomologikal bagi setiap faktor yang dikaji (Hair et. al, 2010). Nilai korelasi keseluruhan antara faktor kajian adalah antara .36 hingga .59 , nilai ini boleh diterima kerana $<.90$ yang menunjukkan tidak wujud masalah multikolineariti antara faktor kajian (Hair et.al, 2010)

Jadual 4

Korelasi Antara Lima Faktor Kajian

\begin{tabular}{ccccccc}
\hline Bil & Faktor & PK & PM & PB & PS & MK \\
\hline 1 & PK & 1 & - & - & - & - \\
2 & PM & $.41 * * *$ & 1 & - & - & - \\
3 & PB & $.47 * * *$ & $.37 * * *$ & 1 & - & - \\
4 & PS & $.46 * * *$ & $.36 * * *$ & $.48 * * *$ & 1 & - \\
5 & MK & $.47 * * *$ & $.53 * * *$ & $.54 * * *$ & $.59 * * *$ & 1 \\
\hline
\end{tabular}

Nota: $* * * p<.001 ; P K=$ pelbagai kemahiran $; P M=$ pengalaman kerja yang bermakna; $P B=$ pengalaman bertanggungjawab terhadap hasil kerja; $P S=$ pengetahuan sebenar hasil kerja; $M K=$ motivasi kerja 


\section{Kesahan Pemodelan Persamaan Berstruktur Lima Faktor Kajian}

Rajah 2 menunjukkan model yang terjana bagi pemodelan persamaan berstruktur lima faktor kajian. Kesahan pemodelan persamaan berstruktur ditentu berdasarkan perbandingan ketepatan padanan dengan model pengukuran keseluruhan akhirnya (Hair et. al, 2010). Pemodelan persamaan berstruktur dibina dengan menukarkan kovarian yang disahkan dalam model pengukuran keseluruhan kepada laluan antara pemboleh ubah. Terdapat satu faktor eksogenus dalam model ini, iaitu faktor pelbagai kemahiran (PK). Secara pratiknya, ia menunjukkan tidak terdapat hipotesis yang dapat meramal faktor ini. Model ini juga turut mengandungi empat pemboleh ubah endogenus terdiri daripada pengalaman kerja yang bermakna (PM), pengalaman bertanggungjawab terhadap hasil kerja (PB), pengetahuan sebenar hasil kerja (PS) dan motivasi kerja guru (MK).

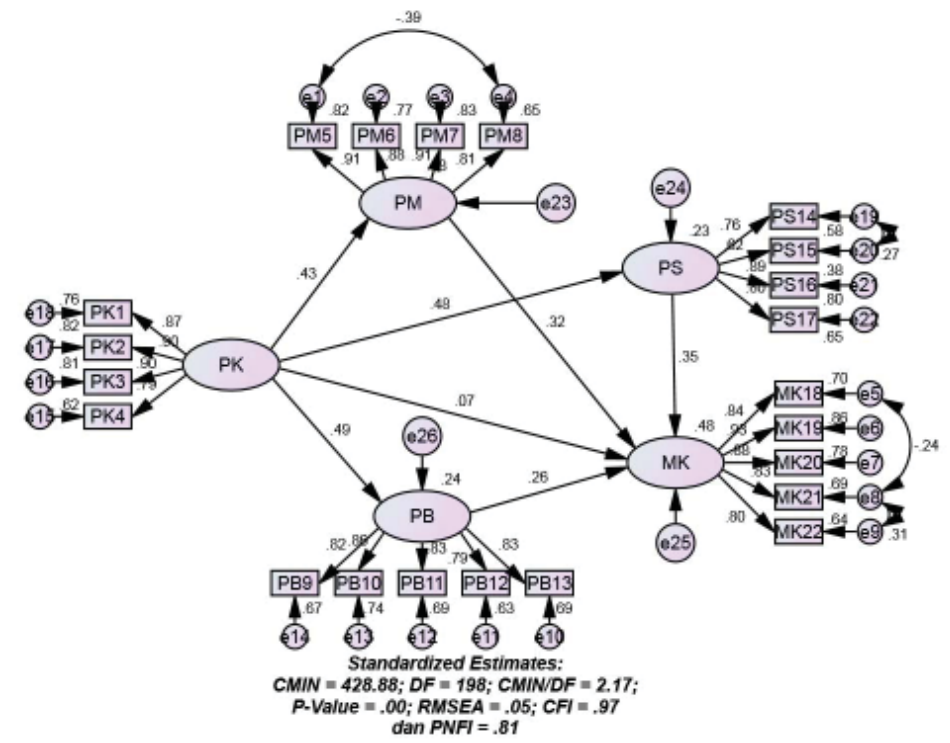

Rajah 2. Pemodelan Persamaan Berstuktur Lima Faktor Kajian

Jadual 5 menunjukkan analisis pemodelan persamaan berstruktur yang terjana mencapai tahap kesepadanan yang baik $(\mathrm{CMIN}=$ 428.88, $\mathrm{DF}=198, \mathrm{CMIN} / \mathrm{DF}=2.17, p=.00, \mathrm{RMSEA}=.05, \mathrm{CFI}$ 
$=.97$ dan PNFI $=.81$ ). Perbandingan ketepatan padanan antara pemodelan persamaan berstruktur yang terjana dengan model pengukuran akhirnya menunjukkan tidak terdapat perbezaan yang ketara. Namun perbandingan petunjuk CMIN, DF, CMIN/DF, RMSEA dan CFI menunjukkan pemodelan persamaan berstruktur yang terjana mencapai ketepatan padanan yang lebih baik berbanding model pengukuran akhirnya (Hair et.al, 2010).

Jadual 5

Perbandingan Ketepatan Padanan Pemodelan Persamaan Berstruktur Dengan Model Pengukuran Akhir

\begin{tabular}{lccc}
\hline \multicolumn{1}{c}{ Petunjuk } & $\begin{array}{c}\text { Nilai } \\
\text { Petunjuk } \\
\text { Diterima }\end{array}$ & $\begin{array}{c}\text { Model } \\
\text { Pengukuran } \\
\text { Akhir }\end{array}$ & $\begin{array}{c}\text { Pemodelan } \\
\text { Persamaan } \\
\text { Berstruktur } \\
\text { Terjana }\end{array}$ \\
\hline Absolute Fit Indices & & & \\
CMIN $\left(\chi^{2}\right)$ & - & 362.69 & 428.88 \\
DF & - & 195 & 198 \\
CMIN/DF & $<3$ & 1.86 & 2.17 \\
PROB $(P-$ Val $)$ & $>.05$ & .00 & .00 \\
RMSEA & $<.08$ & .04 & .05 \\
Incremental Fit Indices & & & .97 \\
CFI & $>.90$ & .98 & .81 \\
Parsimony Fit Indices & & & .81 \\
PNFI & $>.60$ & &
\end{tabular}

\section{DAPATAN KAJIAN}

Objektif Satu: Hubungan langsung faktor pelbagai kemahiran dalam tugas pengajaran dengan motivasi kerja guru

Jadual 6 menunjukkan dapatan analisis bootstrap AMOS 21 bagi hubungan langsung antara faktor pelbagai kemahiran dengan motivasi kerja guru. Hasil kajian menunjukkan tidak terdapat hubungan yang signifikan antara faktor pelbagai kemahiran dengan motivasi kerja guru $(\beta=.07, p=.19$, BC 95\% CI [-.03, .17]). Hal ini bermakna peningkatan penggunaan pelbagai kemahiran oleh guru dalam melaksanakan tugas pengajaran tidak mempengaruhi secara langsung motivasi kerja mereka. 
Jadual 6

Hubungan Langsung Faktor Pelbagai Kemahiran Dengan Motivasi Kerja guru

\begin{tabular}{lcccccccc}
\hline Kesan Laluan & \multicolumn{3}{c}{ Unstandardized } & \multicolumn{5}{c}{ Standardized } \\
\cline { 2 - 9 } & \multicolumn{3}{c}{ Bootstrap BC 95\% CI } & \multicolumn{3}{c}{ Bootstrap BC 95\% CI } \\
\cline { 2 - 9 } & $\begin{array}{c}\text { B-Est } \\
\text { (SE) }\end{array}$ & Bawah & Atas & $\boldsymbol{P}$ & $\begin{array}{c}\text { B-Est } \\
\text { (SE) }\end{array}$ & Bawah & Atas & $\boldsymbol{P}$ \\
\hline Kesan langsung & $\begin{array}{c}.09 \\
(.08)\end{array}$ & -.05 & .25 & .19 & $\begin{array}{c}.07 \\
(.05)\end{array}$ & -.03 & .17 & .19 \\
\hline
\end{tabular}

\section{Objektif Dua: Hubungan langsung faktor pelbagai kemahiran dalam tugas pengajaran dengan pengalaman-pengalaman psikologi}

Jadual 7 menunjukkan hasil analisis bootstrap AMOS 21 bagi hubungan langsung antara faktor pelbagai kemahiran dengan pengalaman-pengalaman psikologi. Dapatan kajian menunjukkan faktor pelbagai kemahiran mempunyai hubungan langsung yang signifikan dan positif dengan pengalaman kerja yang bermakna $(\beta=$ $.43, p=.00$, BC 95\% CI $[.34, .50])$, pengalaman bertanggungjawab terhadap hasil kerja $(\beta=.49, p=.00$, BC 95\% CI $[.39, .57])$ dan pengetahuan sebenar hasil kerja $(\beta=.48, p=.00$, BC 95\% CI $[.41$, .55]). Hal ini bermakna peningkatan dalam penggunaan pelbagai kemahiran untuk melaksanakan tugas pengajaran boleh merangsang pengalaman kerja yang bermakna, pengalaman bertanggungjawab terhadap hasil kerja dan pengetahuan sebenar hasil kerja dalam kalangan guru sekolah menengah kebangsaan harian biasa di negeri Kedah.

Jadual 7

Hubungan Langsung Faktor Pelbagai Kemahiran Dengan Pengalaman-Pengalaman Psikologi

\begin{tabular}{ccccccccc}
\hline Kesan & \multicolumn{3}{c}{ Unstandardized } & \multicolumn{5}{c}{ Standardized } \\
\cline { 2 - 8 } Laluan & \multicolumn{3}{c}{ Bootstrap BC 95\% CI } & \multicolumn{5}{c}{ Bootstrap BC 95\% CI } \\
\cline { 2 - 8 } & $\begin{array}{c}\text { B-Est } \\
(\text { SE) }\end{array}$ & Bawah & Atas & $\boldsymbol{P}$ & $\begin{array}{c}\text { B-Est } \\
\text { (SE) }\end{array}$ & Bawah & Atas & $\boldsymbol{P}$ \\
\hline PK à PM & $\begin{array}{c}.70 \\
.08)\end{array}$ & .55 & .85 & .00 & $\begin{array}{c}.43 \\
.04)\end{array}$ & .34 & .50 & .00 \\
\hline & & & & & & & & (sambungan)
\end{tabular}




\begin{tabular}{ccccccccc}
\hline \multirow{2}{*}{$\begin{array}{c}\text { Kesan } \\
\text { Laluan }\end{array}$} & \multicolumn{3}{c}{ Unstandardized } & \multicolumn{5}{c}{ Standardized } \\
\cline { 2 - 8 } & \multicolumn{3}{c}{ Bootstrap BC 95\% CI } & \multicolumn{5}{c}{ Bootstrap BC 95\% CI } \\
\cline { 2 - 9 } & $\begin{array}{c}\text { B-Est } \\
\text { (SE) }\end{array}$ & Bawah & Atas & $\boldsymbol{P}$ & $\begin{array}{c}\text { B-Est } \\
\text { (SE) }\end{array}$ & Bawah & Atas & $\boldsymbol{P}$ \\
\hline PK à PB & $\begin{array}{c}.57 \\
.06)\end{array}$ & .45 & .69 & .00 & $\begin{array}{c}.49 \\
(.04)\end{array}$ & .39 & .57 & .00 \\
PK à PS & $\begin{array}{c}.69 \\
(.07)\end{array}$ & .56 & .84 & .00 & $\begin{array}{c}.48 \\
(.04)\end{array}$ & .41 & .55 & .00 \\
\hline
\end{tabular}

Objektif Tiga: Kesan Pengantaraan Pengalaman-Pengalaman Psikologi Bagi Hubungan Antara Faktor Pelbagai Kemahiran Dengan Motivasi Kerja Guru

Jadual 8 menunjukkan hasil analisis kesan pengantaraan spesifik dengan menggunakan analisis lanjutan bootstrap IBM SPSS Statistics 22 bagi menentukan kesan tak langsung ketiga-tiga pengantaraan spesifik tersebut. Analisis selang keyakinan $95 \%$ bias diperbetulkan bagi pengalaman kerja yang bermakna $(\beta=.19, t=6.61$, BC 95\% CI $[.15, .26])$, pengalaman bertanggungjawab terhadap hasil kerja $(\beta=$ $.20, t=6.11, \mathrm{BC} 95 \%$ CI $[.14, .28])$ dan pengetahuan sebenar hasil $\operatorname{kerja}(\beta=.28, t=7.76, \mathrm{BC} 95 \% \mathrm{CI}[.21, .36])$ tidak mengandungi nilai sifar. Keputusan ini menunjukkan ketiga-tiga pengalaman psikologi tersebut menjadi pengantara yang signifikan bagi hubungan antara faktor pelbagai kemahiran dalam tugas pengajaran dengan motivasi kerja guru. Perbandingan nisbah kesan menunjukkan pengetahuan sebenar hasil kerja memberi kesan tak langsung yang paling besar (nisbah kesan $=.36$ ) berbanding pengalaman bertanggungjawab terhadap hasil kerja (nisbah kesan $=.26$ ) dan pengalaman kerja yang bermakna (nisbah kesan $=.25)$.

Jadual 8

Kesan Pengantaraan Spesifik Bagi Hubungan Faktor Pelbagai Kemahiran Dengan Motivasi Kerja Guru

\begin{tabular}{|c|c|c|c|c|c|c|}
\hline & \multirow{2}{*}{$\begin{array}{c}\text { Anggaran } \\
\text { Nilai }\end{array}$} & \multicolumn{2}{|c|}{ Nilai Koefisien } & \multicolumn{2}{|c|}{ BC 95\% CI } & \multirow{2}{*}{$P$} \\
\hline & & SE & $\mathbf{t}$ & Bawah & Atas & \\
\hline Kesan Keseluruhan & .77 & .06 & 12.84 & & & $.00 * * *$ \\
\hline Kesan Langsung & .09 & .06 & 1.45 & & & .15 \\
\hline \multicolumn{7}{|c|}{ Kesan Tak Langsung } \\
\hline PM & .19 & .03 & 6.61 & .15 & .26 & $.00 * * *$ \\
\hline
\end{tabular}




\begin{tabular}{lcccccc}
\hline & Anggaran & \multicolumn{2}{c}{ Nilai Koefisien } & \multicolumn{2}{c}{ BC 95\% CI } & \multirow{2}{*}{$\boldsymbol{P}$} \\
\cline { 3 - 6 } & Nilai & SE & $\mathbf{t}$ & Bawah & Atas & \\
\hline PB & .20 & .03 & 6.11 & .14 & .28 & $.00 * * *$ \\
PS & .28 & .04 & 7.76 & .21 & .36 & $.00 * * *$ \\
JUMLAH & .69 & .06 & 12.55 & .59 & .79 & $.00 * * *$ \\
\hline
\end{tabular}

Nota: $* * * p<.001 ; S E=$ standard error $($ ralat piawai) $; t=$ critical ratio $($ nisbah kritikal); $B C=$ bias corrected (bias diperbetulkan); $C I=$ confident interval (selang keyakinan); $P M=$ pengalaman kerja yang bermakna; $P B=$ pengalaman bertanggungjawab terhadap hasil kerja; $P S=$ pengetahuan sebenar hasil kerja

\section{PERBINCANGAN}

Objektif pertama kajian ini adalah untuk meneliti sama ada wujud hubungan langsung antara faktor pelbagai kemahiran dengan motivasi kerja guru. Hasil kajian menunjukkan faktor pelbagai kemahiran dalam tugas pengajaran tidak mempunyai hubungan langsung yang signifikan dengan motivasi kerja guru $(\beta=.07, p=.19)$. Dapatan ini bertentangan dengan kajian-kajian awal yang menunjukkan faktor pelbagai kemahiran mempunyai perkaitan langsung yang signifikan dengan motivasi kerja (Nazila \& Seyed, 2014; Isfahani et. al, 2013; Mohammad Hadi, 2013; Nadeem et. al, 2012; Aneel et. al, 2011; Rabia \& Adnan, 2010). Namun begitu kajian ini menggunakan kerangka konseptual yang berbeza berbanding kajian-kajian lepas. Kajian ini menguji kesan langsung faktor pelbagai kemahiran terhadap motivasi kerja dengan melibatkan tiga pengalaman psikologi sebagaimana disarankan oleh teori ciri-ciri kerja yang menjadi asas kerangka teoritikal kajian. Penggunaan pengalamanpengalaman psikologi dalam pengujian hubungan langsung telah mengurangkan kuasa peramal faktor pelbagai kemahiran terhadap motivasi kerja jika dibandingkan dengan kesan keseluruhan faktor pelbagai kemahiran terhadap motivasi kerja $(\beta=.77, p=.00)$.

Implikasi daripada dapatan ini menunjukkan guru lebih cenderung menggunakan pelbagai kemahiran dalam melaksanakan tugas pengajaran untuk memenuhi tuntutan tugas pengajaran dari aspek pencapaian objektif dan keberkesanan pelaksanaannya. Guru kurang menyedari bahawa penggunaan pelbagai kemahiran dalam melaksanakan tugas pengajaran memberi peluang kepada mereka untuk merasai kecekapan diri. Namun dari satu aspek menunjukkan 
guru lebih memberi fokus kepada usaha menjayakan pelaksanaan tugas pengajaran berbanding meletakkan kepentingan tugas pengajaran untuk diri mereka.

Walau bagaimanapun dapatan bagi objektif kedua kajian menunjukkan faktor pelbagai kemahiran mempunyai hubungan langsung yang signifikan dan positif dengan pengalaman kerja yang bermakna $(\beta=.43, p=.00)$, pengalaman bertanggungjawab terhadap hasil kerja $(\beta=.49, p=.00)$ dan pengetahuan sebenar hasil kerja $(\beta=.48, p=.00)$. Dapatan ini dari satu aspek menyokong teori ciri-ciri kerja tentang hubungan spesifik antara faktor pelbagai kemahiran dengan pengalaman kerja yang bermakna. Namun daripada satu aspek bertentangan dengan andaian teori apabila faktor pelbagai kemahiran turut mempunyai hubungan yang signifikan dengan pengalaman bertanggungjawab terhadap hasil kerja dan pengetahuan sebenar hasil kerja. Walau bagaimanapun jika dilihat secara keseluruhan dapatan ini menyokong kajian-kajian lepas yang menunjukkan faktor pelbagai kemahiran mempunyai hubungan langsung dengan ketiga-tiga pengalaman psikologi (Behson, 2012; Humphrey et. al, 2007).

Dalam hal ini, dapatan objektif kedua menunjukkan penggunaan pelbagai kemahiran dalam melaksanakan tugas pengajaran berjaya membina pengalaman kerja yang bermakna dalam kalangan guru. Hal ini memberi gambaran bahawa penggunaan pelbagai kemahiran mendorong guru untuk membina makna secara peribadi daripada tugas pengajaran yang mereka lakukan dan dianggap berharga mengikut sistem nilai yang menjadi pegangan mereka (Hackman \& Oldham, 1975, 1980). Selain itu, penggunaan pelbagai kemahiran juga berjaya membina pengalaman bertanggungjawab guru terhadap hasil kerja kesan daripada kesedaran bahawa setiap keberhasilan tugas pengajaran berpunca daripada kemahiran yang mereka gunakan. Natijahnya, penggunaan pelbagai kemahiran dapat membina kefahaman dan pengetahuan yang jelas serta berterusan guru terhadap keberkesanan atau kecekapan mereka dalam melaksanakan tugas pengajaran sebagai kerja utama mereka (Hackman \& Oldham, 1980).

Objektif terakhir kajian adalah untuk meneliti kesan pengantaraan pengalaman-pengalaman psikologi bagi hubungan antara faktor pelbagai kemahiran dengan motivasi kerja guru. Kajian 
menunjukkan ketiga-tiga pengalaman psikologi berperanan sebagai pemboleh ubah pengantara yang signifikan. Kajian ini menyokong andaian teori ciri-ciri kerja yang mencadangkan hanya pengalaman kerja yang bermakna memberi kesan pengantaraan untuk hubungan faktor pelbagai kemahiran dengan motivasi kerja (Hackman \& Oldham, 1980; Champoux, 2011; Faturochman, 1997). Namun pada masa yang sama dapatan kajian ini bertentangan dengan cadangan teori ciri-ciri kerja apabila pengetahuan sebenar hasil kerja dan pengalaman bertanggungjawab terhadap hasil kerja turut mempunyai kesan pengantaraan bagi hubungan antara faktor pelbagai kemahiran dengan motivasi kerja guru.

Penelitian terhadap nisbah kesan mendapati pengetahuan sebenar hasil kerja memberi kesan pengantaraan yang lebih besar (nisbah kesan $=.36$ ) berbanding pengalaman kerja yang bermakna (nisbah kesan $=.25$ ). Tambahan pula, nisbah kesannya juga lebih kecil berbanding pengalaman bertanggungjawab terhadap hasil kerja (nisbah kesan $=.26$ ). Hal ini menunjukkan pengalaman kerja yang bermakna merupakan pemboleh ubah pengantara yang kurang penting secara relatif tetapi mempunyai kesan pengantaraan yang signifikan berbanding dua pengalaman psikologi lain. Sehubungan dengan itu, dapatan kajian ini menyokong analisis meta oleh Humphrey et. al (2007) yang menunjukkan ketiga-tiga pengalaman psikologi yang dicadangkan oleh teori ciri-ciri kerja memberi kesan pengantaraan yang signifikan bagi hubungan antara faktor pelbagai kemahiran dengan motivasi kerja.

Berdasarkan nisbah kesan, pengetahuan sebenar hasil kerja memberi kesan pengantaraan yang paling penting bagi hubungan antara faktor pelbagai kemahiran dengan motivasi kerja. Dapatan ini adalah selari dengan analisis meta yang dilakukan oleh Humphrey et. al (2007). Justeru dalam konteks bidang pendidikan, dapatan ini menunjukkan guru-guru sekolah menengah kebangsaan harian biasa di negeri Kedah mempunyai kefahaman dan pengetahuan yang jelas serta berterusan terhadap keberkesanan atau kecekapan mereka dalam melaksanakan tugas pengajaran. Faktor ini menyebabkan mereka sentiasa aktif dan bermotivasi dalam memikirkan masalah pengajaran yang dihadapi, gigih mencari jalan penyelesaian, sedia mengorbankan masa untuk memastikan masalah yang dihadapi dapat diatasi serta menerima pandangan yang berpotensi untuk menyelesaikan masalah (Dewey, 1933). 
Sementara itu, penggunaan pelbagai kemahiran untuk melaksanakan tugas pengajaran di sekolah telah berjaya membina pengalaman bertanggungjawab terhadap hasil kerja. Hal ini secara langsung menunjukkan guru sekolah menengah kebangsaan harian biasa di negeri Kedah mempunyai rasa bertanggungjawab dan akauntabiliti secara peribadi terhadap hasil kerja yang dilakukan. Dapatan ini mengukuhkan lagi analisis meta oleh Humphrey et. al (2007), iaitu penggunaan pelbagai kemahiran mempunyai hubungan dengan pengalaman bertanggungjawab terhadap hasil kerja. Dalam konteks ini, pengalaman bertanggungjawab menjadi salah satu faktor penting mempengaruhi keberhasilan proses pengajaran dan pembelajaran (Dahlgren \& Hammar, 2009; Lauermann \& Karabenick, 2011, 2013). Sebagaimana yang dinyatakan oleh Lauermann \& Karabenick (2011), pengalaman bertanggungjawab dapat menjelaskan rasa dalaman dan komitmen guru untuk menyumbang kepada keberhasilan matlamat pengajaran dan mempertahankan keberhasilan matlamat tersebut. Rentetan daripada itu, pengalaman bertanggungjawab akan mempengaruhi guru berusaha memahami secara mendalam tentang tanggungjawab mereka dan situasi yang memerlukan mereka bertanggungjawab secara peribadi untuk setiap hasil kerja yang dilakukan (Lauermann \& Karabenick, 2013). Situasi ini merangsang motivasi guru dalam melaksanakan tugas pengajaran sebagai kerja utama mereka di sekolah.

Meskipun berbeza disiplin ilmu, dapatan kajian turut membuktikan bahawa selain dua kesan pengantaraan di atas, faktor pelbagai kemahiran juga berjaya membina pengalaman kerja yang bermakna yang boleh menghasilkan makna secara peribadi dan dianggap berharga kepada guru berdasarkan sistem nilai yang menjadi pegangan mereka. Dapatan kajian ini adalah selari dengan hasil kajian oleh Hackman dan Oldham (1975, 1980). Natijahnya, pengalaman kerja bermakna turut mempengaruhi pola rutin kerja ataupun tugas pengajaran guru sebagaimana yang digagaskan oleh Bessette (2003), pengalaman kerja bermakna mampu memberi kesan positif kepada persepsi dalaman individu terhadap tugas yang dilakukan dan merupakan keinginan asas untuk mencari makna dan tujuan utama dalam kerja yang dilakukan. Keadaan ini menggambarkan perasaan positif yang terhasil daripada interaksi antara guru dengan organisasi kerja dan kandungan kerja (Kristensen et. al, 2005. Kesan persepsi positif secara dalaman terhadap tugas pengajaran menyebabkan guru dimotivasikan secara intrinsik untuk melaksanakan kerja 
dan rasa untuk melaksanakannya dipandu oleh dorongan dalaman (Treadgold, 1999). Hal ini membantu guru untuk memahami dan mentafsirkan pengalaman mereka dalam melaksanakan kerja serta mendefinisikan nilai-nilai yang menjadi asas tindakan mereka (Yalom, 1980). Proses ini membantu guru membina motivasi dalam melaksanakan tugas pengajaran mereka di sekolah.

\section{KESIMPULAN}

Kajian ini hanya menyokong sebahagian daripada cadangan teori ciri-ciri kerja oleh Hackman dan Oldham (1980). Walaupun kesan pengantaraan pengalaman kerja yang bermakna wujud dalam hubungan antara faktor pelbagai kemahiran dengan motivasi kerja, namun pada masa yang sama pengalaman bertanggungjawab terhadap hasil kerja dan pengetahuan sebenar hasil kerja juga memberi kesan pengantaraan yang signifikan. Malah kesan pengantaraan pengetahuan sebenar hasil kerja dan pengalaman bertanggungjawab terhadap hasil kerja lebih besar berbanding pengalaman kerja yang bermakna. Kajian ini telah memberi implikasi secara langsung terhadap cadangan hubungan spesifik teori ciri-ciri kerja. Secara realiti hubungan spesifik yang dicadangkan oleh teori ciri-ciri kerja sukar berlaku kerana ciri tingkah laku pekerja yang bersifat kompleks dan sukar diramalkan disebabkan pelbagai komitmen kerja yang perlu dipenuhi yang boleh memberi kesan kepada emosi, mental dan fizikal (Humphrey et. al, 2007; Bakker \& Demerouti, 2007; Demerouti et. al, 2001).

Secara praktis, dapatan kajian ini boleh digunakan oleh pengurus pada peringkat sekolah untuk mempengaruhi motivasi kerja guru. Kaedah pengayaan kerja (job enrichment) dengan menggabungkan pecahan-pecahan tugas bagi membentuk keseluruhan satu kerja boleh memaksimumkan penggunaan kemahiran yang pelbagai dalam kalangan guru. Hal ini kerana guru menjadi lebih jelas tentang tugas yang perlu mereka laksanakan dan kemahiran-kemahiran yang perlu digunakan dalam melaksanakan tugas mereka. Kaedah ini secara langsung dapat mengurangkan konflik peranan dan ketidakjelasan peranan dalam kalangan guru untuk melaksanakan tugas di sekolah. Kajian ini hanya memberi tumpuan kepada faktor pelbagai kemahiran dalam mempengaruhi motivasi kerja, walaupun ketigatiga pengalaman psikologi yang dicadangkan oleh teori ciri-ciri 
kerja dikaji secara langsung. Bagi tujuan kajian pada masa depan, penyelidik dicadangkan memberi tumpuan kepada faktor-faktor lain seperti identiti tugas, signifikasi tugas, autonomi dan maklum balas kerja sebagai peramal motivasi kerja melalui pengalamanpengalaman psikologi. Kajian ini juga hanya terbatas kepada proses membina motivasi kerja guru, bagi kajian selanjutnya tumpuan boleh diberikan kepada kesan berantaian motivasi kerja kepada pemboleh-pemboleh ubah seperti prestasi kerja, tahap produktiviti, komitmen kerja, kecenderungan pusing ganti kerja dan kesetiaan kepada organisasi. Kajian ini hanya melibatkan responden dalam kalangan guru sekolah menengah kebangsaan harian biasa di negeri Kedah. Oleh itu, dapatan kajian ini bukan menggambarkan trend pembinaan motivasi kerja bagi semua guru di Malaysia. Sehubungan itu, kajian selanjutnya perlu melibatkan guru-guru di negeri lain.

\section{RUJUKAN}

Ab Halim Tamuri \& Mohamad Khairul Azman Ajuhary. (2010). Amalan pengajaran guru pendidikan Islam berkesan berteraskan konsep mu'allim. Journal of Islamic and Arabic Education, 2 (1), 43 - 56.

Abdul Wahab Ismail Gani, Kamaliah Siarap dan Hasrina Mustafa. (2006). Penggunaan komputer dalam pengajaranpembelajaran dalam kalangan guru sekolah menengah: Satu kajian kes di Pulau Pinang. Kajian Malaysia. XXIV (1\&2). $203-225$.

Ahmad Mahdzan Ayob. (2007). Kaedah penyelidikan sosioekonomi (Edisi ketiga). Kuala Lumpur, Malaysia: Dewan Bahasa dan Pustaka.

Aneel Kumar, Qaisar Abas, Ikhtiar Ali Ghumro, \& Ashi Zaeshan. (2011). Job characteristic as predictors of job satisfaction and motivation. Asian Journal of Business and Management Science, 1 (4), 206 - 216.

Babbie, E. (2008). The basics of social research (4th ed.). Belmont, CA: Thomson Wadsworth.

Bakker, A. B., \& Demerouti, E. (2007). The job demands-resources model: State of the art. Journal of Management Psychology, $22(3), 309-328$.

Bessette, J. L. (2003). Meaningful work: A Study of Human Resources Professionals in the Nevada Gaming Industry. Reno, US: University of Nevada. 
Behson, S. J., Eddy, E. R., \& Lorenzet, S.J. (2000). The importance of the critical psychological states in the job characteristic model: A meta analytic and structural equation modelling examination. Current Research in Social Psychology, 5 (9), $170-189$.

Behson, S. J. (2012). Using relative weights to reanalyse research on the job characteristic model. Journal of Organizational Psychology, 12 (2), $71-81$.

Boud, D., Keogh, R., \& Walker, D. (1985). Reflection: Turning experience into learning. London, UK: Kogan Page.

Boonzaier, B., Ficker, B., \& Rust, B. (2001). A review of research on the job characteristics model and the attendant job diagnostic survey. South African Journal of Business Management, 32 (1), $11-34$.

Bremner, N., \& Carriere, J. (2011). The effect of skill variety, task significance, task identity and autonomy on occupational burnout in a hospital setting and the mediating effect of work meaningfulness. Ottawa, Canada: Telfer School of Management.

Brislin, R. W. (1970). Back-translation for cross-culture research. Journal of Cross-Cultural Psychology, 1(3), 185-216.

Champoux, J. E. (2011). Organizational behaviour: Intergrating individuals, groups, and organizations. New York, US: Routlegde Taylor \& Francis Group.

Chua Yan Piaw. (2011). Kaedah penyelidikan edisi kedua. Kuala Lumpur, Malaysia: McGraw-Hill (Malaysia).

Cohen, L., Manion, L., \& Morrison, K. (2011). Research methods in education (7th ed.). New York, US: Routledge Taylor \& Francis Group.

Creswell, J. W. (2012). Educational research: planning, conducting and evaluating quantitative and qualitative research (4th ed.). Boston, MA. Pearson Education.

Csikszentmihalyi, M. (1990). Flow: The psychology of optimal experience. New York: Harper and Row.

Dahlgren, M. A., \& Hammar C, E. (2009). Learning for professional life: Student teachers' and graduated teachers' views of learning, responsibility and collaboration. Teaching and Teacher Education, 25(8), 991-999.

Demerouti, E., Bakker, A. B., Nachreiner, F., \& Schaufeli, W.B. (2001). The job demands-resources model of burnout. Journal of Applied Psychology, 86, 499-512. 
Dewey, J. (1933). How we think. A restatement of the relation of reflective thinking to the educative process. Boston. D.C. Heath and Company.

Faturochman. (1997). The job characteristics theory: A review. Buletin Psikologi, 2, 1 - 13.

Fried, Y., \& Ferris, G.R. (1987). The validity of the job characteristics model: A review and meta analysis. Personnel Psychology, 40, $287-322$.

Fornell, C., Larcker, D.F., 1981. Evaluating structural equation models with unobservable variables and measurement error. Journal of Marketing Research 18 (1), 39-50.

Gay,L. R, \& Diehl, P.L. (1996). Educational research: Competencies for analysis and application (5th ed.). Upper Saddle River, NJ: Prentice-Hall.

Hackman, J.R., \& Oldham, G.R. (1975). Development of the job diagnostic survey. Journal of Applied Psychology, 60(2), $159-170$.

Hackman, J.R., \& Oldham, G.R. (1976). Motivation through the design of work: Test of a theory. Organizational Behavior and Human Perfomance, 16, 250 - 279.

Hackman, J.R., \& Oldham, G.R. (1980). Work redesign. Reading, MA: Addison-Wesley.

Hair, J.F., Black, W.C., Babin, B.J., \& Anderson, R.E. (2010). Multivariate data analysis (7th ed). New Jersey, USA: Prentice Hall.

Hairiah Munip. (2012). Aplikasi pendekatan konstruktivisme dalam reka bentuk pengajaran berasaskan komputer: Pengaruhnya terhadap pencapaian berdasarkan aras kognitif pelajar. Diperoleh daripada http://ipgktb.edu.my/

Hogan, E.A., \& Martell, D.A. (1987). A confirmatory structural equation analysis of the job characteristics model. Organizational Behavior and Human Decision Processes, $39,242-263$.

Humphrey, S.E., Nahrgang, J.D., \& Morgeson, F.P. (2007). Integrating motivational, social and contextual work design features: A meta analytic summary and theoretical extension of the work design literature. Journal of Applied Psychology, 92 (2), $1332-1356$. 
Isfahani, S. S., Bahrami, S., \& Torki, S. (2013). Job characteristics perception and intrinsic motivation in medical record department staff. Medical Archives, 67 (1), 51 - 55. doi: 10.5455/medarh.2013.67.

Kementerian Pelajaran Malaysia. (2012). Laporan awal pelan pembangunan pendidikan Malaysia 2013 - 2025. Putrajaya, Malaysia: Kementerian Pelajaran Malaysia.

Kline, R. B. (2005). Principles and practice in structural equation modelling (2nd ed.). New York, USA: The Guilford Press.

Kristensen, T.S., Hannerz, H., Hogh, A., \& Borg, V. (2005). The Copenhagen psychosocial questionnaire-a tool for the assessment and improvement of the psychosocial work environment. Scandinavia Journal of Work, Environment and Health, 31 (6), 438 - 449.

Lauermann, F., \& Karabenick, S. A. (2011). Taking teacher responsibility into account (ability): Explicatingits multiple components and theoretical status. Educational Psychologist, 46(2), 122-140.

Lauermann, F., \& Karabenick, S. A. (2013). The meaning and measure of teachers' sense of responsibility for educational Outcomes. Teaching and Teacher Education, 30, 13-26.

Lee-Ross, D. (1996). The attitudes and work motivation of seasonal hotel worker. (Unpublished doctoral dissertation). APU, Cambridge.

McMillan, J. H., \& Schumacher, S. (2006). Research in education. Boston, US: Pearson Education.

Meor Ibrahim Kamaruddin \& Nurul Amira Ahmad. (2013). Persepsi guru sains terhadap kaedah pembelajaran koperatif $(P K)$ berdasarkan kemahiran sosial pelajar dan minat guru. Diperoleh daripada http://eprints.utm.my/

Miller, K. (2003). Conducting cognitive interviews to understand question-response limitations among poorer and less educated respondents. American Journal of Health Behavior, 27 (3), $264-272$.

Mohammad Hadi Asgari. (2013). Studying the relationship between job characteristics and internal motivation among employees of Islamic Azad University of Mazandran province. International Research Journal of Applied and Basic Sciences, 4(10), 3085 - 3092. 
Morgeson, F. P., \& Humphrey, S.E. (2006). The work design questionnaire (WDQ): Developing and validating a comprehensive measure for assessing job design and the nature of work. Journal of Applied Psychology, 91, 1321 - 1339.

Nadeem Bhatti, Anwar Ali Shah G. Syed ,\& F.M. Shaikh. (2012). Job satisfaction and motivation in banking industry in Pakistan. Journal of Asian Business Strategy, 2 (3), 54 - 62.

Nazila Karimi, \& Seyed Ali Siyadat. (2014). Prediction of working motivation through job characteristics: The role of internal motivation, general and growth satisfaction. International Journal of Education and Applied Sciences, 1(1), 48 - 54.

Noraini Idris. (2010). Penyelidikan dalam pendidikan. Kuala Lumpur, Malaysia: McGraw Hill (Malaysia).

Norashid Othman \& Hamzah Md. Omar. (2014). Beban tugas dan motivasi pengajaran guru di sekolah menengah Daerah Ranau. Journal Pemikir Pendidikan, 5, 35 - 57.

Preacher, K. J., \& Hayes, A. F. (2008). Asymptotic and resampling strategies for assessing and comparing indirect effects in multiple mediator models. Behavior Research Methods, 40(3), 879 - 891. doi: 10.3758/BRM.40.3.879.

Rabia Hadi \& Adnan Adil. (2010). Job characteristics as predictors of work motivation and job satisfaction of bank employees. Journal of the Indian Academy of Applied Psychology, 36 (2), $249-299$.

Renn, R.W., \& Vandenberg, R. J. (1995). The critical psychological states: An underrepresented component in job characteristics research. Journal of Management, 21(2), 279 - 303.

Richey, R. C., \& Klein, J. D. (2007). Design and development research. Mahwah, NJ: Lawrence Erlbaum Associates Publisher.

Shahril @ Charil Marzuki. (2005). Amalan pengajaran guru yang berkesan: Kajian di beberapa sekolah menengah di Malaysia. Diperoleh daripada http://www.ipbl.edu.my/Shani, N., \& AnandKumar, V. (2011). A study on job characteristics and internal work motivation among ICICI bank employees. International Journal of Management, 2(2), 56 - 65.

Shrout, P. E., \& Bolger, N. (2002). Mediation in experimental and nonexperimental studies: New procedures and recommendations. Psychological Methods, 7 (4), 422 - 445. 
Sidek Mohd Noah. (2002). Reka bentuk penyelidikan: Falsafah, teori dan praktis. Serdang, Malaysia: Universiti Putra Malaysia.

Siti Fatimah Ahmad, \& Ab Halim Tamuri. (2010). Persepsi guru terhadap penggunaan bahan bantu mengajar berasaskan teknologi multimedia dalam pengajaran j-Qaf. Journal of Islamic and Arabic Education, 2(2), 53 - 64.

Tabachnick, B. G., \& Fidell, L. S. (2007). Using multivariate statistics (5th ed.).. Boston, USA. Pearson Education.

Treadgold, R. (1999). Transcendent vocations: their relationship to stress, depression and clarity of self concept. Journal of Humanistic Psychology, 39 (1), 81 - 105.

Umi Nadiha Mohd Nor, Zamri Mahmod \& Jamaludin Badusah. (2011). Penerapan kemahiran generik dalam pengajaran bahasa Melayu sekolah menengah. Jurnal Pendidikan Bahasa Melayu, 1 (2), $71-84$.

Yahya Othman (2009). Keutamaan bahan dalam pengajaran dan pembelajaran bahasa Melayu pada sekolah-sekolah di Selangor Darul Ehsan Malaysia. Sosiohumanika, 2 (2), 215 - 226.

Yalom, I. D. (1980). Existential psychotherapy. New York, USA: Basic Books

Zainuddin, A. (2012). Research methodology and data analysis (5th ed.). Shah Alam, Malaysia: Universiti Teknologi Mara Publication Centre (UiTM Press). 